\title{
Cultivating your leadership skills Online resources to develop and strengthen your leadership role
}

S uccessful leadership can be daunting, though some people make it look effortless. One secret to their success is knowing that leadership has many components that make up the big picture. Focusing too closely on one aspect of leadership, such as mentoring or planning models or vision, may cause you to lose your way. Finding your way and cultivating all of your leadership skills is a challenge and a commitment, both personally and professionally.

When I participated in Florida's statewide Sunshine State Library Leadership Institute in 2004-05, our facilitator, Elizabeth Curry, modeled part of our ten sessions on the popular book The Leadership Challenge by James M. Kouzes and Barry Z. Posner. There are five practices from the book that make up their definition of successful leadership: 1) modeling the way, 2) inspiring a shared vision, 3) challenging the process, 4) enabling others to act, and 5) encouraging the heart. Access: http://www. leadershipchallenge.com.

\section{Modeling the way}

Leaders must model the way for others. In order to model, leaders should have a clear sense of their own values and their own direction in life. Leaders then must be able to communicate these values, taking into account personality types, communication styles, and generational differences, and set an example. Verbalizing your values and then following through with actions consistent with those values increases your integrity and gives others confidence in you.

\section{Clarifying your values}

Knowing your own values and communicating them is a building block of leadership.
- Clarifying and Applying Personal Values by Scott Williams. Access: http://www.wright.edu/ scott.williams/skills /values.htm.

- Checklist for Personal Values by Charlotte Roberts. Access: http://www. selfcounseling.com/help/personalsuccess /personalvalues.html.

\section{Acknowledging generational differences}

Who doesn't work in a library with several generations represented? Acknowledging those different perspectives can help you plan for change.

- Bridging the Generation Gap by Deborah Laure1. Access: http:// www.scls.info/ce/program/documents /BridgeGenGap-3hrprog.pdf.

- Generational Differences by Dennis Gaylor. Access: http://www.ats. wilmore.ky.us/academics/biacl/notebooks/07 /watson_appendix1.pdf.

Assessing different personality types with personality inventories

In addition to generational differences, everyone has a separate personality type that influences how they work, how they handle conflict, and how they relate to others. These inventories are available for a fee.

- The Keirsey Temperament Sorter. Access: http://www.keirsey.com.

- Myers-Briggs Type Indicator. Access: http://www.myersbriggs.org.

Robin Kear is a reference librarian at Nova Southeastern University in Fort Lauderdale, Florida, e-mail: kear@nsu. nova.edu

(c) 2006 Robin Kear 
- Enneagram Types. Access: http:// www.enneagraminstitute.com.

\section{Inspiring a shared vision}

Sincere passion for your vision, the ability to effectively communicate it, and the skill to have others relate to it are essential leadership skills. Anyone making decisions for your institution or department must be able to make choices based on how they fit into the shared vision and mission. Input from those affected by the vision is also necessary for success.

\section{Building a vision}

Your vision can come from a lifelong passion, on the job experience, a desire to change the way things are, or a desire to continue things as they are. Whatever it is, it must be developed, articulated, and accessible to others.

- Building a Leadership Vision by Donald E. Hanna. Access: http://www. educause.edu/ir/library/pdf/ERM0341.pdf.

- The Goals Grid by Fred Nickols. Access: http://home.att.net/ nickols/goals_grid.htm.

\section{Framing your message}

No one listens to your vision in a vacuum. Everyone brings his or her own experience and perspective to any message that you are sending. Framing that message is important to make your vision relevant.

- Strategic Frame Analysis. Access:http:// www.frameworksinstitute.org/strategicanalysis /index.shtml.

- Message Framing. Access: http:// www.advocacy.org/communicate/message framing.htm.

\section{Storytelling techniques}

Incorporate stories from your own experience when sharing a vision. Listeners remember a story long after they forget your speech.

- Storytelling Do's by the Advanced Public Speaking Institute. Access: http://www. public-speaking.org/public-speaking -storydo-article.htm.

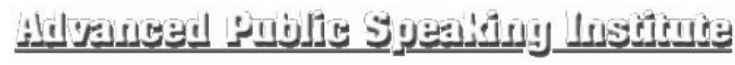

- Storyteller Articles. Access: http://www. storyteller.net/articles.

\section{Planning models}

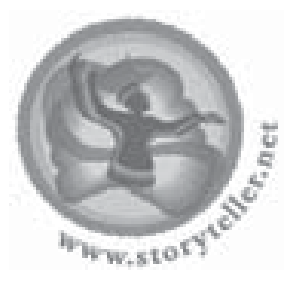

Having a strategic plan to accompany a shared vision makes it a reality.

- Strategic Planning by Carter McNamara. Access: http://www.managementhelp. org/plan_dec/str_plan/str_plan.htm.

- Strategic Planning in the University by Kathleen A. Paris. Access: http://www. wisc.edu/oqitest/strplan/struniv.html.

\section{Challenging the process}

Opportunities can be created through hard work, come as a result of success or failure, or be discovered by scanning the immediate and distant environments. You must stay flexible and gauge opportunities to improve the institution within the range of your vision, even if it requires reexamining your vision. Challenging the decision-making process within your institution is key to change and growth. Support for professional development will bring new ideas to the workplace. The authority for everyone to act on and nurture opportunities is also important to challenging the process.

\section{Power, authority and influence}

The congruence and difference between power, authority, and influence is interesting and can help you create change even if you are not in an "official" upper-level position.

- Power: The Ability to Influence Others from the University of Pittsburgh. Access: http://www.placement.pitt.edu /emergingleaders/handouts_articles /power_ability_influence_article.pdf.

\section{Persuasion and styles of influence}

Persuasion and influence will help communicate a message of change.

- An Introduction to Social Influence by Kelton Rhoads. $A C$ cess: http://www.workingpsychology. com/intro. html.

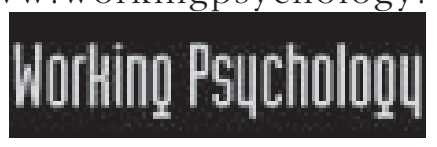




\section{Be a change agent}

Change agents recognize when change is necessary. Searching for opportunities and seeking out fresh ideas can help you become a change agent.

- What Makes a Good Change Agent? by Dagmar Recklies. Access: http://www. themanager.org/Strategy/change_agent.htm.

- The Enduring Skills of Change Leaders by Rosabeth Moss Kanter. Access: http://www.pfdf.org/leaderbooks/121 /summer99/kanter.html.

\section{Enabling others to act}

Through your everyday example, appropriate transparency, accessibility, and definable long-term growth and goals, those around you must trust that you make good decisions in the interest of the institution. In turn, you must trust that those around you also make good decisions. Respect is a result of trust, and collaboration easily follows respect. Weathering problems and surprises is made easier by fostering mutual trust and respect in the organization. Continually recognizing and rewarding the hard work and dedication of everyone, in the way they prefer, is necessary to keep a healthy environment that allows others to act.

\section{Building trust}

Just as in personal relationships, trust is hard to gain and easy to lose in the workplace.

- Great Place to Work Model. Access: http://www.greatplacetowork.com/great /index.php.

\section{Cooperation and collaboration}

Determining conflict handling styles can help foster cooperation and collaboration. Library 2.0 technologies can help collaboration online.

- Thomas Kilman Conflict Mode Inventory (TKI). Access: http://pcs.hmc. washington.edu/odt/html/m-tki.htm.

- Collaborative Tools in Libraries wiki. Access: http://www.libsuccess. org/index.php?title=Collaborative_Tools_in _Libraries.

\section{Listening skills}

We filter, misunderstand, misinterpret, or forget most of what we hear; that's why effective listening skills are so important.

- Importance of Effective Communication, Listening Skills by Edward G. Wertheim. Access: http://web.cba.neu.edu / ewertheim/interper/commun.htm\#active.

\section{Mentoring}

Mentoring is the exchange of knowledge and wisdom between a more experienced professional and a new one. The traditional model of mentoring is changing to include online social networking.

- Mentoring Resources from WebJunction. Access: http://webjunction.org /do/Navigation?category $=11567$.

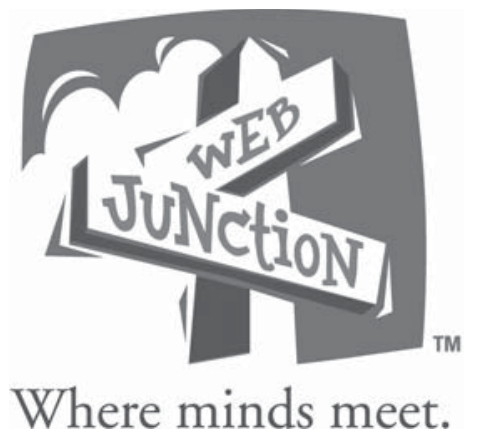

- Mentoring for Librarians by Shoshana Kaufmann. Access: http://lacuny.cuny.edu /committees/professional/climbing /mentoring.pdf.

\section{Encouraging the heart}

Celebrate values and victories by creating a sense of community, but don't forget to do it your own way and be creative, sincere, and authentic. It is important to also show appreciation for both individual excellence and group success.

\section{Coaching, supervising, and morale}

Coaching employees instead of supervising them results in continuous performance improvement and better morale. Coaches are partners and can be peers or managers.

- Separating Coaching from Supervising by Cathy A. Toll. Access: http://www. teacherleaders.org/misc/CoachNotSupvr.pdf. 


\section{Feedback}

Feedback is a two-way process. Soliciting feedback from your peers or those you manage can open your eyes to how others perceive you. Feedback should be an ongoing process.

- 360 Degree Feedback by Susan M. Heathfield. Access: http://humanresources. about.com/od/360feedback/a/360feedback. htm?nl=1.

\section{Recognition and celebration}

Celebrating and recognizing positive contributions will have a positive impact. For those who don't like public acknowledgement, something private may suffice; just ask them which they prefer.

- Recognition Resources from Bob

Nelson. Includes low-cost recognition ideas. Access: http://www.nelson-motivation.com /resources.cfm.

\section{NEIS ON MOIIVATION, ING.}

\section{National leadership programs}

Leadership classes and institutes offer a way to step out of your daily routine and think about the ideas and techniques that will make you a leader and help advance your career. Learning to have your own vision and learning how and why to lead a diverse group of people takes time and mental energy. The intellectual and personal growth that results from this investment is phenomenal. Another important benefit of in-person training is meeting other potential library leaders whom you can collaborate with in the future.

- ACRL/Harvard Leadership Institute. ACRL in conjunction with the Harvard Leadership Institute offers a weeklong immersion of library leadership for academic librarians. Held in Cambridge, Massachusetts, the institute is designed for library directors and other librarians in prominent positions. Going into its eighth year, the program is usually held in August with the registration deadline in May. Access: http://www.gse.harvard.edu/ ppe /highered/programs/acrl.html.
- Frye Leadership Institute. The Frye Leadership Institute is for academic faculty, librarians, information technologists, and administrators to gather and learn about
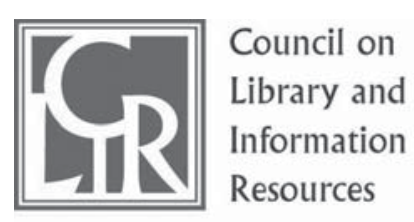

leadership as it applies to higher education. Participants must be nominated by an institution's senior leadership and are selected competitively from all applicants. The institute is an intensive two-week experience at Emory University in Georgia with a required yearlong practicum commitment. The institute is cosponsored by Emory, EDUCAUSE, and the Council on Library and Information Resources. Access: http://www.fryeinstitute. org.

- Living the Future. Held every two years, the Living the Future conference meets in Tucson and is cosponsored by the University of Arizona, ACRL, and the Association of Research Libraries (ARL) Office of Leadership and Management Services. Started in 1996, this conference focuses firmly on future trends and how to plan and develop them. The next conference will be in April 2008. The proceedings from the 2006 conference are online. Access: http://www. library.arizona.edu/conferences/ltf/2006 /proceedings.html.

- Research Libraries Leadership Fellows Program (RLLF). The highly competitive RLLF Program is an executive leadership program jointly designed and sponsored by six ARL member libraries: University of California-Berkeley, Harvard University's Widener Library, University of Minnesota, North Carolina State University, Pennsylvania State University, and University of Toronto. The program offers development of future senior-level leaders in large research libraries. Access: http://www.arl.org/leadership/rllf /index.html.

\section{Private leadership organizations}

Finding the leaders among private leadership organizations and businesses can be 
difficult. Most are for-profit companies that offer workshops and trainings or private consulting. These are a few that have other resources available on their Web sites.

- Center for Creative Leadership. The Center for Creative Leadership is a nonprofit, educational institution with international reach. For more than three decades, its mission has been to advance the understanding, practice and development of leadership for the benefit of society worldwide. Access: http://www.ccl.org.

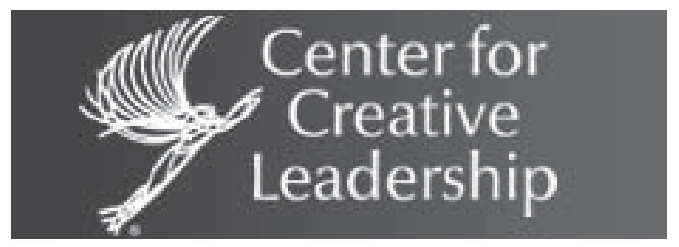

- Greenleaf Center for ServantLeadership. The Greenleaf Center is an international, not-for-profit institution headquartered in Indianapolis, Indiana. The organization's goal is to help people understand the principles and practices of servant-leadership. Its founder, Robert $\mathrm{K}$. Greenleaf, spent most of his first career in management, research, and development for AT\&T and then embarked on a consulting career in leadership. Access: http://www. greenleaf.org.

- Leadership Advantage. This private company in Olney, Maryland, has useful articles about leadership and work environments for free on its consulting Web site. Access: http://www.leadershipadvantage. com/news.shtml.

- Management Library. This free resource compiled by Authenticity Consulting contains valuable and useful information on a variety of management topics, including leadership, strategic planning, and communication. Access: http://www. managementhelp.org.

\section{Professional association leadership development}

Keeping up with developments in the leadership field can be aided by our own professional associations.
- Association of Research Libraries (ARL) Leadership Development. The ARL Leadership Development enabling program was created to meet ARL's 2005-2009 strategic goals. Currently, a task force on leadership development is defining this new direction for ARL and offerings may be available in the future. Access: http://www.arl.org /leadership/index.html.

- Focus On: Leading Library Transformation. Sponsored by ARL, this series of articles concentrates on different aspects of library management and professional development. Access: http://www.arl.org/leadership /resources/focus/index.html.

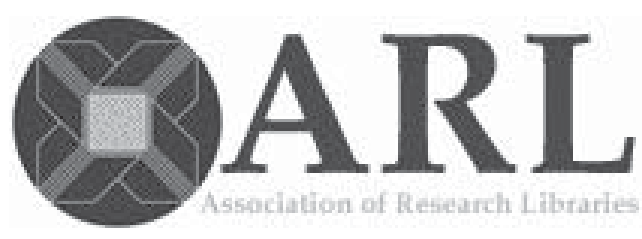

- Library Administration and Management Association (LAMA). A division of ALA, LAMA is dedicated to developing current and future library leaders. Access: http://www.ala.org/ala/lama/lama.htm.

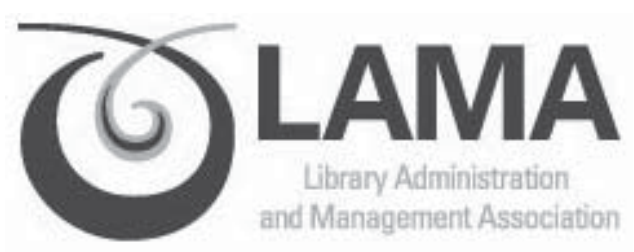

\section{Conclusion}

Becoming an inspiring and effective leader means believing; believing in yourself, believing in others, and believing in what you do.

Having a passion for what you do and the goals you want to achieve can encourage others to work with you. The grander your vision is, the more you will need the collaboration and cooperation of others to make it a reality.

Cultivating your own leadership skills, regardless of what type of position you hold, helps you and others to achieve those goals. Don't forget to enjoy the ups and downs, and have fun along the way. $z$ 